\title{
Impact of ASEAN-India Free Trade Area on Indonesian Palm Oil Export: A Gravity Model Approach
}

\author{
Goldenny Glorius*, Heri Akhmadi and Aris Slamet Widodo
}

\author{
Department of Agribusiness, Faculty of Agriculture, Universitas Muhammadiyah Yogyakarta \\ *Corresponding author. Email: goldeniglorius@gmail.com
}

\begin{abstract}
This research focuses on investigating whether Indonesia's membership in the ASEAN-India Free Trade Area (AIFTA) increases Indonesia's palm oil exports to India. The analysis technique used in this study is gravity model with estimates using panel data. The data derived from 36 partner countries of Indonesia's palm oil exports in period of 1999-2018 have been applied to analyze the factors that affect Indonesia's palm oil exports. The result showed that population, exchange rate, and partner countries arable land have significant impact on Indonesian palm oil exports, while distance and GDP of destination countries show insignificant result. Indonesia's membership in AIFTA has been proven not to have a significant impact on Indonesia's palm oil exports.
\end{abstract}

Keywords: AIFTA Impact, FTA, Gravity Model, Palm Oil Export.

\section{INTRODUCTION}

Indonesian agricultural sector has excellent development prospects as a foreign exchange resource compare to industrial and mining sectors. There are several main agricultural commodities that play a major role in the Indonesian economy, one of the agricultural is oil palm. Recently, Indonesia is the biggest palm oil producer in the world as well as the same time the largest exporter of palm oil.

Indonesia's palm oil production in 2018 account 41.67 million tons. While in 2022 it is projected that Indonesia's palm oil production will reach 48.44 million tons [1]. The existence of Indonesian palm oil industry which produces palm oil, and its decline has become the mainstay of plantation commodity exports. To continue to increase palm oil exports to major destination countries such as India, the European Union, Bangladesh, Singapore and other countries, Indonesia continues to strive to improve trade performance by entering into a series of free, bilateral, regional and multilateral free trade agreements.

Free trade is an economic concept that refers to the sale of products between countries without export-import tariffs or other trade barriers. Indonesia actively joins several FTAs to facilitate exporters in Indonesia in trading activities. The facilities that can be obtained by the FTA are cost reduction due to the elimination or reduction of tariffs, procedures and regulations with partner countries [2]. Thus, this is expected to have a positive impact on Indonesia's economic growth.

ASEAN-India Free Trade Area (AIFTA) is one of the regional economic agreements which in 2010 was signed by
Indonesia and the countries which are members of ASEAN [3]. This collaboration is aimed at increasing trade cooperation between ASEAN Countries and India. After the free trade agreement was held between the ASEAN countries and India. Viewed from its development India is an export destination country with great potential for the development of Indonesia's palm oil exports which incidentally Indonesia exports more palm oil to India than to ASEAN countries.

Indonesia's palm oil exports to India since 1999-2009 tend to increase. In 1999 Indonesia exported palm oil valued at US \$ 382 million and continued to increase slowly until 2006, in 2007 Indonesia exported palm oil twice the amount compared to the previous year with a value of US \$2.180 million and continued to increase until 2009 with total export worth 3,339 million US \$ [4].

After the implementation of AIFTA, in 2010-2018 Indonesia's palm oil exports to India tended to fluctuate but with an upward trend. In 2010 the value of palm oil exports to India amounted to 4,340 million US \$ and then increased in 2011 with a value of 5,256 million US \$ but in 2012 to 2015 Indonesia experienced a drastic decrease with the export value in 2015 only amounting to 3,217 million US \$. Then in 2016 and 2017 Indonesia's palm oil exports again experienced a large increase. In 2018 the number of palm oil exports to India will again decline with an export value of 3.559 million US \$. This can be seen in Figure 1 regarding Indonesia's palm oil exports to India [4]. 


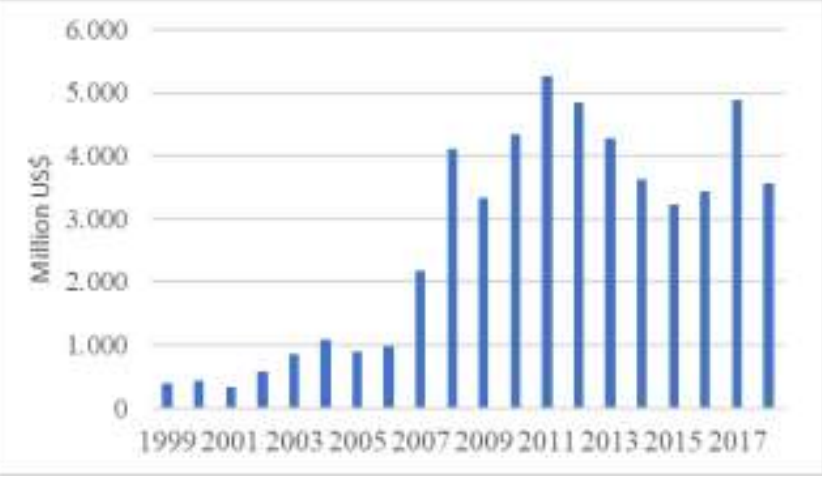

Figure 1 Indonesian Palm Oil Exports to India 1999-2018

AIFTA is a free trade agreement made to improve ASEAN member countries export performance. Previous research related to the AIFTA has been carried out, however, research on the impact of the AIFTA on Indonesia's palm oil exports is still limited. A research on the impact of AIFTA on trade between Indonesia with India showed that AIFTA has no influence on trade between the two countries then the impact of the Indonesia-India FTA on the agricultural sector and Indonesia's economy as a whole by using the Global Trade Analysis Project model which is linked to the general equilibrium model (CGE) [5]. Recent research conducted by on fluctuations in Indonesia's CPO exports to India after the ratification of AIFTA showed that there are significant benefits for Indonesia's CPO exports [6].

According to the above exploration, it is interesting to examine whether the ASEAN-India Free Trade Area (AIFTA) affects the performance of Indonesia's palm oil export. It is also important to know whether these facts influence Indonesia's decision to participate in a free trade agreement. Therefore the purpose of this study is to find out the factors that influence Indonesia's palm oil exports to importing countries after the ratification of AIFTA and to determine the impact of the ASEAN-India free trade agreement (AIFTA) on Indonesia's palm oil exports.

\section{RESEARCH METHOD}

This research is a quantitative descriptive study of 36 partner countries of Indonesian palm oil export from 1999 to 2018. The reason of this period is because Indonesia has been joining most of free trade agreements since 1999, either bilaterally, regionally, or multilateral, and 2018 is the latest data that can be collected. This study also wants to demonstrate the development of palm oil export before and after the ratification of AIFTA from 2010 to 2018.

The Gravity Model was used with estimates using panel data. The Gravity Model explains the volume of traditional trade between the two countries $i$ and $j$ in terms of income in countries, their populations, and the distance between them. The variables used in this study to analyze the impact of AIFTA on Indonesian palm oil include: Indonesia's real GDP, the real GDP of Indonesia's partner countries, the economic distance between Indonesia and Indonesia's palm oil importers, Indonesia's real exchange rates, dummy variables, namely: dummy signing of trade in goods agreements in AIFTA, Indonesian dummy as an exporter to AIFTA member and non-members countries, and Indonesian dummy as importers from countries other than AIFTA members. From this explanation can be made the following equation:

$$
\begin{aligned}
\operatorname{LnE}_{\mathrm{ijt}}= & \beta 0+\beta 1 \operatorname{LnGDP}_{\mathrm{it}}+\beta 2 \operatorname{LnGDP}_{\mathrm{jt}}+\beta 3 \mathrm{LnDist}_{i j}+ \\
& \beta 4 \mathrm{LnP}_{\mathrm{it}}+\beta 5 \mathrm{LnP}_{\mathrm{jt}}+\beta 6 \mathrm{LnLand}_{\mathrm{jt}}+\beta 7 \mathrm{LnEx}_{\mathrm{it}}+ \\
& \beta 8 \mathrm{LnEx}_{\mathrm{jt}}+\beta 9 \mathrm{AIFTA}_{\mathrm{ij}}+\varepsilon_{\mathrm{ijt}}
\end{aligned}
$$

Where:

$\mathrm{E}_{\mathrm{ijt}} \quad$ : Total exports of Palm Oil from Indonesia (i) to the importing country $(\mathrm{j})$

LnGDP $_{\text {it }}$ : The sum of Indonesia's GDP

LnGDP $_{\mathrm{jt}}$ : Total GDP of the importing country

LnDist $_{\mathrm{ij}}$ : Geographical distance between the capital city of Indonesia (i) and the importing country (j)

$\mathrm{LnP}_{\mathrm{it}}$ and $\mathrm{LnP}_{\mathrm{jt}}$ : Population of Indonesia and importing countries

LnLand $_{j t}$ : Total importing arable land in hectares.

LnExit and LnExjt: The exchange rates of Indonesian and importing countries.

AIFTA : Dummy variable AIFTA

Independent variables consist of Indonesian real GDP $\left(\operatorname{LnGDP}_{i t}\right)$, partner countries real GDP $\left(\operatorname{LnGDP}_{\mathrm{jt}}\right)$, the population of Indonesia $\left(\mathrm{LnP}_{i t}\right)$, the population of the importing country $\left(\mathrm{LnP}_{\mathrm{jt}}\right)$ and exchange rate Indonesia $\left(\mathrm{LnEx}_{\mathrm{it}}\right)$, and the exchange rate importing countries $\left(\operatorname{LnEx}_{\mathrm{jt}}\right)$ obtained from The World Bank, arable land (Landjt) obtained from the Food and Agriculture Organization (FAO), distance between countries $\left(\right.$ LnDist $\left._{i j}\right)$ obtained from the Center d'Etudes Prospectiveset d'Informations Internationales (CEPII), and palm oil exports ( $\left.\mathrm{LnE}_{\mathrm{ijt}}\right)$ were obtained from the United Nations Commodity trade database (UN Comtrade) using HS 1511 code as the dependent variable. The type of data used is panel data. Panel data is a combination of cross section data and time series data. There are three methods in estimating the regression model with panel data, namely Pooled Least Square or ordinary using the Ordinary Least Square (OLS), Fixed Effect Model (FEM), and Random Effect Model (REM) [7].

\section{RESULT AND DISCUSSION}

Table 1 shows the estimation results of gravity model of Indonesia's palm oil exports to 36 importing countries in the period 1999-2018. Based on the results of Chow Test and Hausman Test it can be concluded that the best model used in estimating the impact of AIFTA on Indonesian palm oil exports is Random Effect Model. The random effect model estimate panel data where interruption variables may be interrelated between time and between individuals. In the Random Effect model, intercept differences are accommodated by the error terms of each country. The advantage of using the Random Effect model is to eliminate heteroscedasticity. This model will also have implications 
for the parameter estimation results will become more efficient [8].

Table 1 Estimation Results of Indonesia's Palm Oil Exports to Importing Countries with a Random Effect Model.

\begin{tabular}{lrrr}
\hline \multicolumn{1}{c}{ Variable } & \multicolumn{1}{c}{ Coefficient } & \multicolumn{1}{c}{ t-Statistic } & \multicolumn{1}{c}{ Prob. } \\
\hline LnGDP $_{\text {it }}$ & 1.282509 & 3.779920 & $0.0002^{* * *}$ \\
LnGDP $_{\text {jt }}$ & -0.039691 & -0.316355 & 0.7518 \\
LnDIST $_{\text {ij }}$ & 0.232895 & 0.348821 & 0.7273 \\
LnP $_{i t}$ & 3.926933 & 1.003850 & 0.3158 \\
LnP $_{\text {jt }}$ & 1.321027 & 4.853675 & $0.0000^{* * *}$ \\
LnLAND $_{j t}$ & -0.491070 & -2.852872 & $0.0045^{* * *}$ \\
LnEX $_{\text {it }}$ & -0.094944 & -0.142874 & 0.8864 \\
LnEX $_{\text {jt }}$ & -0.278215 & -3.102405 & $0.0020 * * *$ \\
AIFTA $_{i j}$ & -0.200446 & -0.203690 & 0.8387 \\
Source: Primary data analized using Eviews 9. $^{* * * S i g n i f i c a n t ~ a t ~ 1 \% ~}$ & &
\end{tabular}

The coefficient of determination $\left(\mathrm{R}^{2}\right)$ showed that 58.4 point of the variation of palm oil exports can be explained within the model. While the remaining 41.6 point can be explained by other variables outside the model. The small number of R square are common for Random Effect Model estimation. Several studies resulted on R square only $57 \%$ [9], and $50 \%$ [10], and even there is other study that only shows R square of $48 \%$ [11]. Moreover, the results of F-test showed a $\mathrm{P}$ value of 0.0000 which is less than 0.05 , which is can be concluded that all variables significantly influence the growth of Indonesia's palm oil exports (simultaneously).

The results of the data that have been processed in this study, shows the variable gross domestic product (GDP) of Indonesia has positive and significant results on Indonesia's palm oil exports, amounting to 1.282509 point in 36 destination countries for Indonesia's palm oil exports from 1999-2018. It means that every $1 \%$ increase in gross domestic product (GDP) will increase Indonesia's palm oil exports by $1.28 \%$. This result is in line with other research which explains that the effect of GDP on exports can be explained through the concept of vent for surplus proposed by Adam Smith, where exports are related to a surplus or excess output of domestic production output. An increase in the production surplus marked by GDP growth will encourage exports to increase because excess domestic output will be channelled through exports [12].

The gross domestic product (GDP) of the importing country has a negative and insignificant result on Indonesia's palm oil exports of -0.039691 point, assuming the number of independent variables. It means that every $1 \%$ increase in the gross domestic product (GDP) of the destination country, will reduce Indonesia's palm oil exports by $0.04 \%$. The negative relationship of the importing country's GDP to Indonesian exports is contrary to the theory. However, research similar to that carried out by [13] said that it can be caused if the GDP of the country of origin of imports can be increased but not followed by an increase in export growth. Then another study stated that the decline in the value of American cocoa imports might be caused by cocoa being inelastic goods and cocoa products have a small share of food expenditure in America and an increase in GDP need not necessarily be interpreted as an increase in the import of cocoa beans [14].

The distance between Indonesia and importing countries surprisingly showed positive and insignificant impact on Indonesia's palm oil exports of 0.232895 point, assuming the number of independent variables. It means that every $1 \%$ increase in the distance of importing countries will increase Indonesia's palm oil exports by $0.232 \%$. The results obtained are not in accordance with the theory of gravity where the distance affects the interaction between two objects. The greater the distance of the destination country from Indonesia, the greater the cost of transportation for CPO trade from Indonesia [15]. However, there is several research that says that distance does not really affect the literation between the two countries [16]. One of the reasons is because technological advancements can reduce transportation costs in a sustainable manner. With the advancement in technology, moving goods becomes increasingly cheap and fast in a sustainable manner. Another reason is technological advancements have been offset by significant changes in the reduction in input and operational costs of vessels so that transportation costs have decreased [17]. Therefore, economic distance is not the dominant determinant of a country's decision to export or import because it only affects a fraction of the costs given the high technological progress.

The results of population of Indonesia shows a positive but insignificantly affect Indonesian palm oil export. The trend of Indonesia's palm oil export volume is always fluctuating in each country every year, there are times when it increases but there are times when it decreases. While trends in population data in destination countries continue to increase. This shows that the population in the country has no significant effect on the increase in palm oil exports in Indonesia with destination countries [18]. With the continued increase in population it will be possible to expand the area of oil palm plantations by increasing the workforce in the palm oil sector so that it will increase production and exports.

Moreover, population of importers can be seen that has a result that is positive and significant on the export of Indonesian palm oil which amounted to 1.321027 point. It means that every $1 \%$ increase in the population of the importing country will increase Indonesia's palm oil exports by $1.32 \%$. The size of the population in a country shows a large market potential for exporting countries. The population is an indication to increase the amount of exports, so that it can have a positive effect. Countries with large populations can become a potential market for Indonesia to be more developed, such as India, the European Union and China which are the largest export destination countries for Indonesian CPO commodities and have a population that continues to grow each year. 
The expected also shown on variable of arable land of partner countries which have negative and significant affect to export of Indonesian palm oil is at -0.491070 point. Mean that of $1 \%$ increase of arable land of Importers, will reduce Indonesia's palm oil exports amounted to $12,49 \%$. This variable has a negative sign statistically significant effect on agricultural exports. This means the extent of fertile land that can be used owned by partner countries has an effect on Indonesia's palm oil exports. Fertile land is characterized by crop production for food or feed supply, 'normal' permeability and large soil erosion potential, in principle annual plants have great potential in the area of existing arable land so that countries with large arable land areas will be sufficient needs in the country [19].

Variable exchange rate of Indonesia did not significantly affect Indonesia's palm oil exports, while the variable exchange rate of importers have negative and significant effect to the export of palm oil in which every 1 percent increase in the exchange rate of India, will reduce Indonesia's palm oil exports to 0.18 percent. The exchange rate increases, or the currency of the exporting country depreciates, so that the price of the product in the exporting country will be cheaper so that it encourages demand for products from other countries. The flow of export trade will increase because demand for CPO products increases. The stability of the exchange rate of Indonesian currencies against other countries' currencies is an important condition for CPO commodity trading [15]. Another research stated that if a country's exchange rate against the dollar increases, this means that the country's currency is depreciating so that it will automatically raise the cost of importing raw materials used for production activities [20]. In this case, the importing country will reduce its imports because there will be an increase in import costs.

The membership of AIFTA agreement shows insignificant impact on Indonesia's palm oil exports. From an Indonesian point of view, it can be said that the initial purpose and motivation on joining of AIFTA, to increase trade, especially Indonesian palm oil exports, was not achieved. It is indicated in the AIFTA variable which shows negative towards Indonesia's exports are with the value of 0.200446 point, but not significant. The insignificant effect of AIFTA on palm oil exports is likely due to the slow growth of agricultural commodity liberalization, one of which is because agriculture is often excluded from tariff reductions in free trade agreements and even if entered into agreements, reducing agricultural commodity tariffs often takes longer than other commodities. Another study concluded that Indonesia's membership in the ASEAN China Free Trade Agreement (ACFTA) will face the threat of rising labour costs that will result in less competitive Indonesian products in the global market [21]. This in line with other study [22], which stated that Indonesia's FTA partners will benefit more than Indonesia itself. Another explanation for AIFTA's effect on the Indonesian exports is that before AIFTA was implemented, Indonesia's export levels had reached a normal pattern because since 1988 the performance of Indonesia's palm oil exports to India had a positive trend in the majority and a reduction in import duty rates had been put in place before AIFTA. When trade between the two countries has reached a normal point, then the space for trade growth will be increasingly narrow. With narrow space for growth, policies to increase trade through tariff reduction schemes become ineffective.

\section{CONCLUSION}

Based on the results of result and discussion, it can be concluded that GDP of Indonesia, population and real exchange rate of importer countries, and arable land significantly effect on Indonesia palm oil exports. Moreover, Indonesia's participation on AIFTA showed insignificantly effect on Indonesia's palm oil exports.

\section{REFERENCES}

[1] Ministry of Agriculture, Outlook Kelapa Sawit (Palm Oil Outlook), 2019.

http://epublikasi.setjen.pertanian.go.id/download/file/5 48-outlook-kelapa-sawit-2019.

[2] H. Akhmadi, Assessment the Impact Of Asean Free Trade Area (AFTA) on Exports of Indonesian Agricultural Commodity, Agrar. J. Agribus. Rural Dev. Res. 3 (2017) 9-14. https://doi.org/10.18196/agr.3139.

[3] ASEAN Secretariat, ASEAN - India Free Trade Area, ASEAN Secr. (2012).

https://asean.org/?static_post=asean-india-free-tradearea-3.

[4] UN Comtrade, United Nation Commodity Trade Database - Indonesian Palm Oil Exports, (2019). https://comtrade.un.org/.

[5] R. Kustiari, The Impacts Of The Indonesia-India Free Trade Agreements On Agricultural Sector Of Indonesia : A CGE Analysis, J. Agro Ekon. 35 (2017) 33-48. https://doi.org/10.21082/jae.v35n1.2017.33-48.

[6] A. Bernaz, Indonesian Crude Palm Oil (CPO) Export Fluctuations to India After the Ratification of the Asean-Indian Free Trade Agreement (AIFTA), JOM FISIP. 6 (2019) 1-13.

[7] J. Wooldridge, Introductory Econometrics : A Modern Approach 5th Edition, 5th ed., South-Western Educational Publishing, 2015.

[8] A.T. Basuki, Panel Data Regression Teaching Materials, 2016.

[9] C. Morland, F. Schier, H. Weimar, The structural gravity model and its implications on global forest product trade, Forests. 11 (2019). https://doi.org/10.3390/f11020178.

[10] S. Aliyu, S. Bawa, Gravity Model by Panel Data Approach: Empirical Evidence from Nigeria, Int. J. Trade Glob. Mark. 8 (2015) 42-57.

[11] M. Sinaga, R. Bukit, E. Keulana, Analysis Of Influence Of Tariffs Of Import Duty, Exchange Rate, Import Value And Import Volume On Income Of Import Duty In Indonesia With Free Trade Agreement (FTA) As Moderating Variable, J. PUBLIC BUDGETING, Account. Financ. 17 (2018) 1-8. 
[12] A.P. Kurniawati, Studi empiris model gravitasi ekspor Indonesia tahun 2005-2015 (An empirical study of gravity model for Indonesian exports period 20052015), Universitas Muhammadiyah Yogyakarta., 2018.

[13] N. Andrian, Dampak ACFTA Terhadap Kreasi dan Diversi Perdagangan Ikan Hidup Indonesia, 2014.

[14] O. Yeboah, S. Shaik, S. Wozniak, A. Allen, Does the WTO Increase Trade? The Case of U. S. Cocoa Imports from WTO-Member Producing Countries, J. Food Distrib. Res. 42 (2011) 78-88.

[15] A. Sari, D. Hakim, L. Anggraeni, Analysis of the Effects of Non-Tariff Measures on Indonesia's Crude Palm Oil (CPO) Commodity Exports to Major Export Destination Countries., J. Econ. Dev. Policy. 3 (2018) 111-135. https://doi.org/10.29244/jekp.3.2.111-135.

[16] J. Bhagwati, A. Panagariya, Why Growth Matters: How Economic Growth in India Reduces Poverty and the Lessons for other Developing Countries, Reg. Sci. 92 (2013) 887-889. https://doi.org/10.1111/pirs. 12072.

[17] D. Hummels, Transportation costs and international trade in the second era of globalization, J. Econ. Perspect. 24 (2007) 237. https://doi.org/10.1257/jep.21.4.237.

[18] E. Nurhayati, S. Hartoyo, S. Mulatsih, Analysis of Indonesian Clove Export Development., J. Dev. Econ. Policy. 7 (2018) 21-42.

[19] T.M. Bachmann, Hazardous Substances and Human Health, 1st ed., ScienceDirect, 2006.

[20] R. Puspitaningrum, Pengaruh Tingkat Inflasi, Tingkat Suku Bunga SBI, Dan Pertumbuhan Ekonomi Terhadap Nilai Tukar Rupiah Studi Pada Bank Indonesia Periode Tahun 2003-2012, J. Adm. Bisnis. 8 (2014).

http://administrasibisnis.studentjournal.ub.ac.id/index.p $\mathrm{hp} / \mathrm{jab} /$ article/view/348.

[21] F. Riswati, I. Warsito, Challenge for ASEAN-China Free Trade Agreement on Indonesia Employment, Econ. J. Emerg. Mark. 2 (2010) 89-100. https://journal.uii.ac.id/JEP/article/view/2387.

[22] A. Booth, China 's Economic Relations with Indonesia: Threats and Opportunities, J. Curr. Southeast Asian Aff. 30 (2011) 141-160. https://doi.org/10.1177/186810341103000207. 